\title{
Telerehabilitation and face-to-face rehabilitation on tolerance to exercise and quality of life of COVID-19 survivors: a study protocol
}

\author{
Telerehabilitação e reabilitação presencial na tolerância ao exercício e qualidade de vida de \\ sobreviventes da COVID-19: um protocolo de estudo
}

Telerehabilitación y rehabilitación presencial sobre la tolerancia al ejercicio y la calidad de vida de los supervivientes del COVID-19: un protocolo de estudio

Bruna T. S. Araújo ORCID: https://orcid.org/0000-0001-7754-4397 Federal University of Pernambuco, Brazil E-mail: brunathays.araujo@gmail.com

Daniella Cunha Brandão

ORCID: https://orcid.org/0000-0001-8805-6815 Federal University of Pernambuco, Brazil E-mail: daniellacunha@hotmail.com

Ana Eugênia V. R. Barros

ORCID: https://orcid.org/0000-0001-8495-9865

Federal University of Pernambuco, Brazil

E-mail: aaninhavasconcelos@gmail.com

Maria Paula dos Santos Silva

ORCID: https://orcid.org/0000-0003-3803-5746

Federal University of Pernambuco, Brazil

E-mail: paula.santossilva@ufpe.br

Samara de Menezes Lopes

ORCID: https://orcid.org/0000-0002-9640-6325

Federal University of Pernambuco, Brazil

E-mail: menezes.samara4@gmail.com

Daiara Thatiana Xavier Nunes

ORCID: https://orcid.org/0000-0002-8806-8151

Federal University of Pernambuco, Brazil

E-mail: daiaratxn@gmail.com

Jéssica Costa Leite

ORCID: https://orcid.org/0000-0002-4726-9416

Faculty of Medical Sciences of Campina Grande, Brazil

Federal University of Rio Grande do Norte, Brazil E-mail: jcl.15@hotmail.com

Maria Inês Remígio de Aguiar

ORCID: https://orcid.org/0000-0001-8497-0415

Federal University of Pernambuco, Brazil

E-mail: miremigio@yahoo.com.br

Juliana Andrade Ferreira de Souza

ORCID: https://orcid.org/0000-0002-1236-0340

Federal University of Pernambuco, Brazil

E-mail: juafsouza@yahoo.com.br

Shirley Lima Campos

ORCID: https://orcid.org/0000-0003-3079-8300

Federal University of Pernambuco, Brazil E-mail: shirleylcampos@uol.com.br

Juliana Fernandes

ORCID: https://orcid.org/0000-0002-7509-8853

Federal University of Pernambuco, Brazil

E-mail: julianaferso@gmail.com

Armele Dornelas de Andrade

ORCID: https://orcid.org/0000-0001-9430-4395

Federal University of Pernambuco, Brazil

E-mail: armeledornelas@yahoo.com 


\begin{abstract}
Objective: To verify the effects of face-to-face rehabilitation and telerehabilitation on tolerance to the maximum and submaximal exercise, lung function, fatigue intensity and quality of life of survivors of COVID-19. Methodology: This is a protocol of a longitudinal study, of intervention with a sample for convenience. Adults of both sexes who have been diagnosed with COVID-19 confirmed by RT-PCR will be evaluated. After the assessment, they will receive guidance on how to perform exercises without supervision, will be referred to a face-to-face rehabilitation program or telerehabilitation, according to the results obtained in the six-minute walk test and the presence of comorbidities. Expected Results: Demonstrate the effects of exercise through face-to-face rehabilitation and telerehabilitation after being affected by COVID-19, as well as facilitating the development of treatment protocols aimed at the needs observed, aiming to reduce the repercussions caused by the disease and bring a new look to the physiotherapists who work in clinical practice.
\end{abstract}

Keywords: COVID-19; Quality of life; Exercise tolerance; Telerehabilitation; Rehabilitation; Fatigue.

\begin{abstract}
Resumo
Objetivo: Verificar os efeitos da reabilitação presencial e da telerreabilitação na tolerância ao exercício máximo e submáximo, função pulmonar, intensidade da fadiga e qualidade de vida de sobreviventes do COVID-19. Metodologia: Trata-se de um protocolo de estudo longitudinal, de intervenção com amostra por conveniência. Serão avaliados adultos de ambos os sexos com diagnóstico de COVID-19 confirmado por RT-PCR. Após a avaliação eles receberão orientações sobre como realizar exercícios sem supervisão, serão encaminhados para um programa de reabilitação presencial ou telerreabilitação, de acordo com os resultados obtidos no teste de caminhada de seis minutos e a presença de comorbidades. Resultados Esperados: Demonstrar os efeitos do exercício físico por meio da reabilitação presencial e telerreabilitação após o acometimento pelo COVID-19, além de facilitar o desenvolvimento de protocolos de tratamento voltados às necessidades observadas, visando reduzir as repercussões causadas pela doença e trazer um novo olhar para os fisioterapeutas que atuam na prática clínica.
\end{abstract}

Palavras-chave: COVID-19; Qualidade de vida; Tolerância ao exercício; Telerreabilitação; Reabilitação; Fadiga.

\title{
Resumen
}

Objetivo: Verificar los efectos de la rehabilitación presencial y telerrehabilitación sobre la tolerancia al ejercicio máximo y submáximo, la función pulmonar, la intensidad de la fatiga y la calidad de vida de los supervivientes del COVID-19. Metodología: Se trata de un protocolo de estudio longitudinal, de intervención con muestra por conveniencia. Se evaluarán los adultos de ambos sexos que hayan sido diagnosticados con COVID-19 confirmado por RT-PCR. Tras la valoración, recibirán orientación sobre cómo realizar ejercicios sin supervisión, serán derivados a un programa de rehabilitación presencial o telerrehabilitación, según los resultados obtenidos en la prueba de marcha de seis minutos y la presencia de comorbilidades. Resultados Esperados: Demostrar los efectos del ejercicio a través de la rehabilitación presencial y telerrehabilitación luego de ser afectado por COVID-19, así como facilitar el desarrollo de protocolos de tratamiento dirigidos a las necesidades observadas, con el objetivo de reducir las repercusiones ocasionadas por la enfermedad y aportar una nueva mirada a los fisioterapeutas que trabajan en la práctica clínica.

Palabras clave: COVID-19; Calidad de vida; Tolerancia al ejercicio; Telerrehabilitación; Rehabilitación; Fatiga.

\section{Introduction}

Symptoms of Infection with Coronavirus, called COVID-19 can culminate in a mild and self-limited respiratory disease to severe progressive pneumonia, multiple organ failure and even death (Wang et al., 2020; Wu \& McGoogan, 2020). The Acute Respiratory Discomfort Syndrome (ARDS) can be acquired through several disorders, including pneumonia (Carda et al., 2020), being one of the main complications of COVID-19.

As this is a new disease, the short- and long-term consequences for patients with COVID-19 are still unclear. The predictions are based on the knowledge acquired from the general hospitalized population, especially patients with ARDS. The combination of lung injury from this virus and iatrogenic injury from mechanical ventilation can lead to severe damage to lung tissue, culminating in pulmonary fibrosis (Wang et al., 2020).

The use of sedatives, as well as prolonged rest, can lead to musculoskeletal damage, including decreased muscle strength and physical function (Brower, 2009; Gandotra et al., 2019; Parry et al., 2015). In the long term, the post-intensive care syndrome (Needham et al., 2012) can persist for months or maybe years after hospital discharge and individuals may experience reduced functional capacity, difficulties in activities of daily living and reduced quality of life Cuthbertson et al., 2010; DInglas et al., 2017; Gandotra et al., 2019; Hopkins et al., 2017; Pfoh et al., 2016). 
Even those patients who did not need to be admitted to the Intensive Care Unit (ICU) may have some impairment of physical and respiratory capacity, as well as psychosocial difficulties, as a consequence of the disease, hospitalization and social isolation itself (Organization Pan American Health). Therefore, rehabilitation after this disease is a fundamental component in the continuity of patient care. It is a complex intervention to minimize the difficulties of individuals, promote and optimize functional independence in activities of daily living and maximize opportunities for meaningful participation in society (Simpson \& Robinson, 2020).

It has been suggested that those cases with cardiopulmonary and motor problems that need more attention are followed up in rehabilitation units to improve the chances of recovery, while those cases with few and minor sequelae of the COVID-19 infection may be subjected to home therapy (Brugliera et al., 2020).

Telerehabilitation can be a good choice both for individuals who have difficulties leaving home and for patients who are discharged from hospital rehabilitation and still need to continue their treatment and promote additional recovery. Besides, it allows the burden on hospital services to be reduced (Sheehy, 2020)

This study aims to verify the effects of face-to-face cardiac rehabilitation and telerehabilitation on tolerance to maximum and submaximal exercise, lung function, fatigue intensity and quality of life of COVID-19 survivors.

\section{Methodology}

\section{Study setting}

This is a longitudinal, intervention study with a convenience sample. Patients will be distributed according to the distance covered in the 6-minute walk test (6MWT) and the presence of comorbidities (Table 1). The present study will follow the new guidelines of the CONSORT and SPIRIT Extension for RCTs Revised in Extenuating Circumstances (CONSERVE) (Chan et al., 2015; Orkin et al., 2021). This trial was prospectively registered at clinicaltrials.gov (NCT04767477).

The study evaluations will be carried out at the Physiotherapy Department of the Federal University of Pernambuco (UFPE) and interventions at the Hospital das Clínicas (HC) of Pernambuco or at the homes of individuals who had COVID-19.

\section{Sample size calculation}

To define the sample size, a pilot study will be conducted with 15 individuals. This will be calculated for the variables maximum oxygen consumption and distance travelled. For the largest number found, it will be increased by $20 \%$ to compensate for possible loss of tracking, using the GPower 3.1 software with $\alpha=0.05$ and $80 \%$ power.

\section{Eligibility criteria}

Adults of both sexes, with a laboratory diagnosis of COVID-19, confirmed through RT-PCR, will be evaluated. They must have access to the internet and to some device (smartphone, computer or notebook) that allows participation in the call center.

Individuals with orthopedic or neurological diseases that make it impossible to perform the cardiopulmonary test and exercises will be excluded, as well as individuals with difficulties in understanding and that present psychological changes that make it difficult or impossible to understand the information presented.

\section{Procedures}

The protocol will be carried face-to-face at the Hospital das Clínicas of Pernambuco or virtual, through the Google meet platform. Screening of study participants will be done in the main reference centres in Recife, serving the population with 
Covid-19. Besides, it will also be carried out through its dissemination on social media and interested parties may contact the research team.

\section{Outcome measures}

Primary outcomes will be maximum and submaximal functional capacity, intensity and impact of fatigue, while secondary outcomes will be lung function and quality of life.

\section{Cardiopulmonary Exercise Test (CPET)}

The cardiopulmonary exercise test (CPET) is used to assess maximum functional capacity, determination of maximum power and exercise tolerance, is considered the gold standard for assessing aerobic performance. Ventilation (VE), carbon dioxide production (VCO2), oxygen consumption (VO2), among other variables, will be measured. This test will be performed using the treadmill ramp protocol (Centurium 300, Micromed, Brazil), using the ErgoPC Elite ${ }^{\circledR}$ software associated with the electrocardiogram (Micromed, Brazil) with 12 channels. To assess respiratory variables, a gas analyzer (CortexMetalyzer II, Germany) will be used, which has an extremely sensitive sensor, which detects numerous ventilatory variables, being coupled to the patient's face through a mask.

To ensure that patients obtained maximum effort during the exam, only exams in which patients had a respiratory exchange ratio $(\mathrm{R})>1.1$ were considered. All patients were instructed not to perform unnecessary efforts, avoid excesses on the previous day, avoid sedatives and excessive consumption of tea or coffee on the day of the exam and were instructed to use sneakers or flexible shoes to perform the exam.

\section{Spirometry}

The evaluation of lung function will be performed using digital spirometry (Micro Medical Microloop MK8®, Rochester, England). The individual will be positioned in a sitting position, with their feet flat on the floor, an upright spine and the use of a mouthpiece and nose clip. At least three forced vital capacity (FVC) and slow vital capacity (FVC) maneuvers will be performed, obeying the two-minute interval between maneuvers, as recommended by the American Thoracic Society (ATS) and pulmonary function guidelines (Graham et al., 2019).

Then, the average of the three measurements performed will be performed and the values will be expressed as a percentage of the normal predicted value for the Brazilian population (Pereira et al., 2007). In addition to the variables already indicated, inspiratory capacity (CI), FEV1, the relationship between FEV1 and forced vital capacity (FEV1 / FVC), peak expiratory flow (PEF) and mean forced expiratory flow between 25\% and 75\% of CVF (FEF 25-75\%).

\section{Six-minute walk test (6MWT)}

To assess submaximal functional capacity, the 6MWT will be performed according to the proposals by the American Thoracic Society (CRAPO et al., 2002). Patients must walk a 30-meter track as quickly as possible, but without running for six minutes. The evaluation can be interrupted at any time, if the patient needs to rest during the test, returning to walking as soon as possible and can be interrupted in case of dizziness, cramps, chest pain or severe dyspnea, sweating or pallor. The test will be monitored before and shortly after its completion, checking the heart rate, blood pressure, peripheral oxygen saturation, respiratory rate, dyspnea index assessed by the modified Borg Scale. 


\section{Fatigue pictogram}

The Fatigue Pictogram is an ordinal scale composed of two questions graded in 5 captioned illustrations that assess the intensity (not at all tired, a little tired, moderately tired, very tired and extremely tired) and the impact of fatigue (I manage to do everything I normally do I do, I can do almost everything I usually do, I can do some of the things I usually do, I just do what I have to do and I can do very little). There are no cutoff points for the diagnosis or classification of the intensity of fatigue (Mota et al., 2009).

\section{Short Form-36 (SF-36)}

Short Form-36 will be used to assess the quality of life. It consists of 36 items divided into eight domains: functional capacity (10 items), physical aspects (4 items), pain ( 2 items), general health status (5 items), vitality (4 items), social aspects ( 2 items) emotional ( 3 items) and mental health ( 5 items). There is also one more question of comparative assessment between current health conditions and those presented a year ago. This questionnaire has a score of zero, corresponding to the worst general health status and the one hundred best health status (Ciconelli et al., 1999).

\section{Global patient change impression scale (PGIC)}

The assessment of treatment satisfaction will be carried out using the Global Patient Impression Scale (PGIC). It is a one-dimensional measure in which individuals evaluate their improvement associated with the intervention on a scale of 7 items ranging from " $1=$ no changes" to " $7=$ much better". This scale will be used in this study to verify patient satisfaction after an exercise protocol (Domingues \& Cruz, 2011).

\section{Interventions}

The clinical history of the participants will be collected and they will answer the Pictogram fatigue and Short form-36 questionnaires. They will then be submitted to an anthropometric assessment using the Multilaser Digi-Health scale and an anthropometer with a limit of 2 meters $(\mathrm{m})$. Vital signs such as blood pressure (aneroid sphygmomanometer and stethoscope Premium), peripheral oxygen saturation ( $\mathrm{SpO} 2)$ and heart rate (G-TECH oximeter, Oled Graph, China), will also be assessed. Subsequently, they will be submitted to pulmonary function assessment, with spirometry and tolerance to maximum exercise through the Cardiopulmonary Exercise Test, performed by a properly trained cardiologist. The following day, the six-minute walk test will be performed.

Participants will be divided into three groups, according to the distance covered in the 6MWT and the presence of comorbidities, to start the corresponding protocol (Table 1). Those who achieve a distance covered $>563$ meters and do not have cardiac or pulmonary comorbidities will receive a guide with orientation, patients with heart disease or pulmonary disease who have a distance covered $>563$ meters will be referred to a telerehabilitation program and those with a distance less than mentioned previously, they will participate in a face-to-face rehabilitation program (Mantha et al., 2020). 12 sessions will be held twice a week for six weeks. At the end of the exercise program, patients will be reassessed using the same tests and will answer the PGIC scale.

The estimated duration of each session will be 60 minutes. To improve adherence to the protocol, participants will receive face-to-face reminders in all face-to-face sessions and mobile text messages for those who will be served remotely. 
Table1. Flowchart for referral of patients to intervention.

\begin{tabular}{ccc}
\hline & Distance covered in the 6MWT (meters) & Comorbidities \\
Face-to-face rehabilitation & $<427$ & Presence or absence of comorbidities \\
& $427-563$ & Presence of heart disease or pneumopathy \\
Telerehabilitation & $>563$ & Presence of heart disease or pneumopathy \\
Orientation & $>563$ & Absence of comorbidities \\
\hline
\end{tabular}

6MWT: 6-minute walk test. Source: Authors.

\section{Face-to-face rehabilitation}

The cardiac rehabilitation protocol will consist of flexibility exercises, aerobic and resistance training, with two sessions per week. Aerobic training will be performed with $60 \%$ to $80 \%$ of the maximum VO2 obtained through the CPET. The exercise will be performed on the treadmill, with a total time of 40 minutes, with 5 minutes of warm-up, 30 minutes of conditioning, 5 minutes of cooling down (Barker-Davies et al., 2020; Carvalho \& Mezzani, 2011).

Resistance training will be performed for upper and lower limbs and the muscles worked will be brachial triceps, brachial biceps and shoulder abductors, quadriceps, hip abductors and sural triceps. The load used in the exercises will be $60 \%$ of the maximum repetition test (1RM), with load progression every six sessions. The exercises are performed in three series of 12 repetitions (Pereira \& Gomes, 2003).

\section{Telerehabilitation Group}

The telerehabilitation protocol will consist of an exercise program supervised using video calls, divided into three phases: flexibility exercise, aerobic training and resistance training, with two exercise sessions per week. To perform the home exercises, some materials will be loaned, such as pulse oximeters, elastic bands and mats for the participants. The training protocol will consist of stretching the muscles of the upper and lower limbs and accessory muscles of breathing. The conditioning phase will consist of stationary walking, side running, jumping jump and stationary running, 3 times of 40 seconds with a 30-second passive rest interval between them. Resistance training will be applied to the muscles of the upper limbs (biceps, triceps, abductors and adductors of the shoulder) and lower limbs (quadriceps, adductors and abductors of the hip and sural triceps) with specific exercises for each musculature, using elastic bands as resistance.

All individuals will be continually asked about the perceived effort using the Effort Perception Scale (Borg, 1990), and if they have a perception equal to or greater than 15 , on this scale, they will be submitted to the Speech Test. This test consists of reading a paragraph to identify whether the patient can speak comfortably (Foster et al., 2008). If he is unable to speak comfortably, presenting pauses in speech, the exercise will be interrupted.

Individuals who present worsening of symptoms, some hemodynamic instability or are not interested in continuing to participate in the study may interrupt the exercise protocol.

\section{Data management}

The data related to recruitment, characteristics of individuals, cases of dropout, as well as the measures of results, will be stored in file folders in a safe place at the Physiotherapy Department of UFPE and personal computer. All data will be inserted in the Microsoft Excel 2010 (Microsoft ${ }^{\circledR}$, EUA). In addition, only the researchers involved in the research will have access to the database. 


\section{Statistical methods}

The information will be presented as means, medians, standard deviations and Confidence interval. The software used for the tabulation and construction of the database will be Microsoft Excel 2010 (Microsoft ${ }^{\circledR}$, USA) and for statistical analysis the Software SPSS Statistics version 22.0. The Kolmogorov-Smirnov test will be used to verify the type of distribution, regarding the normality of the variables to be studied. In order to compare the means of the control and experimental groups, in relation to the variables of interest, the $t$ test will be used for those with normal distribution and the Mann-Whitney test for those that do not have a normal distribution.

Regarding the correlation between variables, in order to find the one (s) that best explains the dependent variables, Pearson's Correlation will be used if all variables are normal, Linear Regression if only the dependent variable is normal or, Spearman correlation if none of the variables are normal.

For qualitative variables, the chi-square test will be used for parameters with normal distribution or Fisher's exact test for parameters that do not reach normality. Taking into account the determination of the treatment effect size, the relative risk (RR), the relative risk reduction (RRR), the absolute risk reduction (RAR) and the number needed to treat (NNT) will be calculated for the dichotomous variables, for the continuous variables, the "Cohen's d" will be calculated.

The 95\% confidence interval will be considered, being significant when $\mathrm{p}<0.05$. The results found will be expressed through tables and graphs. The control variables will be presented especially through tables with data on average and standard deviation.

\section{Data monitoring}

Data collection, progress and security will be monitored by an independent researcher. The data will be analyzed at the end of all recruitment and data collection.

\section{Harms}

Any self-reported adverse effects will be recorded by therapists and / or researchers and reported to the Research Ethics Committee of the Federal University of Pernambuco, Recife, Pernambuco, Brazil.

\section{Auditing}

The progress of the study will be monitored every two months by an independent researcher in order to verify that all stages of the protocol are going according to plan.

\section{Ethics}

The protocol was approved by the Human Research Ethics Committee of the Federal University of Pernambuco (CAAE protocol number: 43314721.6.0000.5208). All individuals will be informed about the research proposal and this will only start after signing the Free and Informed Consent Form (ICF). Any modifications to the protocol will be reported to the Human Research Ethics Committee and the trial record.

\section{Dissemination policy}

The protocol will be disseminated through publication in journals, as well as presentation at congresses. All researchers who contribute to realization, be it conception, conduction, interpretation will be considered authors in the final study. 


\section{Discussion}

Patients who have been affected by COVID-19 can develop persistent dysfunctions of almost all organ systems and present different signs and symptoms. The variability and complexity of the damage caused by this disease, associated with the pre-existing conditions that some patients may present, can make it difficult to target rehabilitation programs (Wade, 2020). This study will be the first to verify the effectiveness of face-to-face and telerehabilitation rehabilitation protocols in tolerance to the maximum and submaximal exercise, lung function, fatigue intensity and quality of life of COVID-19 survivors.

Rehabilitation has been strongly recommended in international guidelines, with increasing evidence that it can improve exercise capacity and quality of life (Barker-Davies et al., 2020). Likewise, it has been shown that telerehabilitation programs are viable, safe and effective, in the elderly population with combined chronic heart and lung diseases, as well as in individuals who have the isolated disorder (Bernocchi et al., 2018; Bourne et al., 2017; Maddison et al., 2019).

The results obtained in this study may contribute to the development of new therapeutic strategies, which help to clarify whether protocols for face-to-face rehabilitation and telerehabilitation can benefit patients recovered from COVID-19.

\section{Strengths and weaknesses of the study}

This work will bring important information to the scientific community and health professionals, about the best forms of intervention and its repercussions on the surviving individuals of COVID-19. The treatment of the manifestations of this disease has still caused several questions and to date, there are few studies with adequate methodology and sample, which address this theme. The results may also contribute to the design of new studies focusing on the rehabilitation of this population and to evidence-based practice. However, due to the nature of the interventions, it will not be possible to blind the participants and therapists. In addition, the allocation for treatment will be made according to the needs of the patients.

\section{Limitations}

Some limitations of this study deserve to be reported. There were strenuous circumstances that led to changes in the work: possible functional impairments that have been observed in patients and reported in the literature, as well as the reduction in the number of patients seen by time in the sector where the collection will be carried out. As impacts of these circumstances on the study, we had the withdrawal of randomization and the control group.

The mitigation strategies adopted were: extended collection period and modification in the data analysis plan.

\section{Funding}

This study was financed in part by CNPQ 421756/2021-7, 40334/2020-5, 428841/2018-0) and Coordenação de Aperfeiçoamento de Pessoal de Nível Superior (CAPES) Finance code 001, Edital Observatório COVID PROPG/PROPESQI UFPE 2020 and FACEPE APQ 0801-4.08/21 and APQ 0249-4.08/20. We also acknowledge the JBS S.A. initiative "Fazer o Bem Faz Bem" for the financial support.

\section{References}

Barker-Davies, R. M., O’Sullivan, O., Senaratne, K. P. P., Baker, P., Cranley, M., Dharm-Datta, S., Ellis, H., Goodall, D., Gough, M., Lewis, S., Norman, J., Papadopoulou, T., Roscoe, D., Sherwood, D., Turner, P., Walker, T., Mistlin, A., Phillip, R., Nicol, A. M., \& Bahadur, S. (2020). The Stanford Hall consensus statement for post-COVID-19 rehabilitation. British Journal of Sports Medicine, 54(16), 949-959.

Bernocchi, P., Vitacca, M., la Rovere, M. T., Volterrani, M., Galli, T., Baratti, D., Paneroni, M., Campolongo, G., Sposato, B., \& Scalvini, S. (2018). Homebased telerehabilitation in older patients with chronic obstructive pulmonary disease and heart failure: A randomised controlled trial. Age and Ageing, 47(1), 82-88.

Borg, G. (1990). Psychophysical scaling with applications in physical work and the perception of exertion. Scandinavian Journal of Work, $16,55-58$. 
Bourne, S., Devos, R., North, M., Chauhan, A., Green, B., Brown, T., Cornelius, V., \& Wilkinson, T. (2017). Online versus face-to-face pulmonary rehabilitation for patients with chronic obstructive pulmonary disease: Randomised controlled trial. BMJ Open, 7(7).

Brower, R. G. (2009). Consequences of bed rest. Critical Care Medicine, 37(10).

Brugliera, L., Spina, A., Castellazzi, P., Cimino, P., Tettamanti, A., Houdayer, E., Arcuri, P., Alemanno, F., Mortini, P., \& Iannaccone, S. (2020). Rehabilitation of COVID-19 patients. Journal of Rehabilitation Medicine, 52(4), 1-3.

Carda, S., Invernizzi, M., Bavikatte, G., Bensmaill, D., Bianchi, F., Deltombe, T., Draulans, N., Esquenazi, A., Francisco, G. E., Gross, R., Jacinto, L. J., Pérez, S. M., O’Dell, M. W., Reebye, R., Verduzco-Gutierrez, M., Wissel, J., \& Molteni, F. (2020). COVID-19 pandemic. What should physical and rehabilitation Medicine specialists do? A clinician's perspective. European Journal of Physical and Rehabilitation Medicine, 56(4), 515-524.

Carvalho, V. O., \& Mezzani, A. (2011). Aerobic exercise training intensity in patients with chronic heart failure: Principles of assessment and prescription. European Journal of Preventive Cardiology, 18(1), 5-14.

Chan, A.-W., Tetzlaff, J. M., Altman, D. G., Laupacis, A., Gøtzsche, P. C., Krleža-Jeric, K., Hrobjartsson, A., Mann, H., Dickersin, K., Berlin, J. A., Dore, C. J., Parulekar, W. R., Summerskill, W. S., Groves, T., Schulz, K. F., Sox, H. C., Rockhold, F. W., Rennie David Moher, D., \& Ka Shing, L. (2015). Declaración SPIRIT 2013: definición de los elementos estándares del protocolo de un ensayo clínico*. Rev Panam Salud Publica, 38(6), 506-514.

Ciconelli, R. M., Ferraz, M. B., Santos, W., Meinão, I., \& Quaresma, M. R. (1999). Tradução para língua portuguesa e validação do questionário genérico de avaliação de qualidade de vida SF-36 (Brasil SF-36). Rev Bras Reumatol, 39(3), 143-150.

Crapo, R. O., Casaburi, R., Coates, A. L., Enright, P. L., Macintyre, N. R., Mckay, R. T., Johnson, D., Wanger, J. S., \& Zeballos, R. J. (2002). American Thoracic Society ATS Statement: Guidelines for the Six-Minute Walk Test. American Journal Of Respiratory And Critical Care Medicin, $166,111-117$.

Cuthbertson, B. H., Roughton, S., Jenkinson, D., Maclennan, G., \& Vale, L. (2010). Quality of life in the five years after intensive care: a cohort study. Critical Care, 14(R6), 1-12.

DInglas, V. D., Aronson Friedman, L., Colantuoni, E., Mendez-Tellez, P. A., Shanholtz, C. B., Ciesla, N. D., Pronovost, P. J., \& Needham, D. M. (2017). Muscle Weakness and 5-Year Survival in Acute Respiratory Distress Syndrome Survivors*. Critical Care Medicine, 45(3), 446-453.

Domingues, L., \& Cruz, E. (2011). Adaptação Cultural e Contributo para a Validação da Escala Patient Global Impression of Change. Ifisionline, 2(1), 31-37.

Foster, C., Porcari, J. P., Anderson, J., Paulson, M., Smaczny, D., Webber, H., Doberstein, S. T., \& Udermann, B. (2008). The Talk Test as a Marker of Exercise Training Intensity. Journal of Cardiopulmonary Rehabilitation and Prevention, 28, 24-30.

Gandotra, S., Lovato, J., Case, D., Bakhru, R. N., Gibbs, K., Berry, M., Clark Files, D., \& Morris, P. E. (2019). Physical function trajectories in survivors of acute respiratory failure. Annals of the American Thoracic Society, 16(4), 471-477.

Graham, B. L., Steenbruggen, I., Barjaktarevic, I. Z., Cooper, B. G., Hall, G. L., Hallstrand, T. S., Kaminsky, D. A., McCarthy, K., McCormack, M. C., Miller, M. R., Oropez, C. E., Rosenfeld, M., Stanojevic, S., Swanney, M. P., \& Thompson, B. R. (2019). Standardization of spirometry 2019 update an official American Thoracic Society and European Respiratory Society technical statement. American Journal of Respiratory and Critical Care Medicine, 200(8), E70E88.

Hopkins, R. O., Suchyta, M. R., Kamdar, B. B., Darowski, E., Jackson, J. C., \& Needham, D. M. (2017). Instrumental activities of daily living after critical illness: A systematic review. Annals of the American Thoracic Society, 14(8), 1332-1343.

Maddison, R., Rawstorn, J. C., Stewart, R. A. H., Benatar, J., Whittaker, R., Rolleston, A., Jiang, Y., Gao, L., Moodie, M., Warren, I., Meads, A., \& Gant, N. (2019). Effects and costs of real-time cardiac telerehabilitation: Randomised controlled non-inferiority trial. Heart, 105(2), 122-129.

Mantha, S., Tripuraneni, S. L., Roizen, M. F., \& Fleisher, L. A. (2020). Proposed Modifications in the 6-Minute Walk Test for Potential Application in Patients with Mild COVID-19: A Step to Optimize Triage Guidelines. Anesthesia and Analgesia, 30(30), 398-402.

Mota, D. D. C. de F., Pimenta, C. A. de M., \& Fitch, M. I. (2009). Pictograma de Fadiga: uma alternativa para avaliação da intensidade e impacto da fadiga Pictograma de Fadiga: uma alternativa para avaliação da intensidade e impacto da fadiga. Rev Esc Enferm USP, $43,1080-1087$.

Needham, D. M., Davidson, J., Cohen, H., Hopkins, R. O., Weinert, C., Wunsch, H., Zawistowski, C., Bemis-Dougherty, A., Berney, S. C., Bienvenu, O. J., Brady, S. L., Brodsky, M. B., Denehy, L., Elliott, D., Flatley, C., Harabin, A. L., Jones, C., Louis, D., Meltzer, W., \& Harvey, M. A. (2012). Improving longterm outcomes after discharge from intensive care unit: Report from a stakeholders' conference. Critical Care Medicine, $40(2), 502-509$.

Orkin, A. M., Gill, P. J., Ghersi, D., Campbell, L., Sugarman, J., Emsley, R., Steg, P. G., Weijer, C., Simes, J., Rombey, T., Williams, H. C., Wittes, J., Moher, D., Richards, D. P., Kasamon, Y., Getz, K., Hopewell, S., Dickersin, K., Wu, T., \& Chan, A. W. (2021). Guidelines for Reporting Trial Protocols and Completed Trials Modified Due to the COVID-19 Pandemic and Other Extenuating Circumstances: The CONSERVE 2021 Statement. JAMA, 326(3), 257265.

Pan American Health Organization (2020). Considerações sobre a reabilitação durante o surto de COVID-19. Iris.paho.org. https://iris.paho.org/handle/10665.2/52103.

Parry, S. M., El-Ansary, D., Cartwright, M. S., Sarwal, A., Berney, S., Koopman, R., Annoni, R., Puthucheary, Z., Gordon, I. R., Morris, P. E., \& Denehy, L. (2015). Ultrasonography in the intensive care setting can be used to detect changes in the quality and quantity of muscle and is related to muscle strength and function. Journal of Critical Care, 30(5), 1151.e9-1151.e14.

Pereira, C. A. de C., Sato, T., \& Rodrigues, S. C. (2007). Novos valores de referência para espirometria forçada em brasileiros adultos de raça branca. $J$ Bras Pneumol, 33(4), 397-406. 
Research, Society and Development, v. 11, n. 2, e3411225356, 2022

(CC BY 4.0) | ISSN 2525-3409 | DOI: http://dx.doi.org/10.33448/rsd-v11i2.25356

Pereira, M. I. R., \& Gomes, P. S. C. (2003). Testes de força e resistência muscular: confiabilidade e predição de uma repetição máxima-Revisão e novas evidências. Rev Bras Med Esporte, 9(5), 325-335.

Pfoh, E. R., Wozniak, A. W., Colantuoni, E., Dinglas, V. D., Mendez-Tellez, P. A., Shanholtz, C., Ciesla, N. D., Pronovost, P. J., \& Needham, D. M. (2016). Physical declines occurring after hospital discharge in ARDS survivors: a 5-year longitudinal study. Intensive Care Medicine, 42(10), $1557-1566$.

Sheehy, L. M. (2020). Considerations for postacute rehabilitation for survivors of COVID-19. JMIR Public Health and Surveillance, 6(2), 1-8.

Simpson, R., \& Robinson, L. (2020). Rehabilitation after critical illness in people with COVID-19 infection. American Journal of Physical Medicine and Rehabilitation, 99(6), 470-474.

Wade, D. T. (2020). Rehabilitation after COVID-19: An evidence-based approach. Clinical Medicine, 20(4), 359-365.

Wang, T. J., Chau, B., Lui, M., Lam, G. T., Lin, N., \& Humbert, S. (2020). Physical medicine and rehabilitation and pulmonary rehabilitation for COVID-19. American Journal of Physical Medicine and Rehabilitation, 99(9), 769-774.

Wang, X., Xu, H., Jiang, H., Wang, L., Lu, C., Wei, X., Liu, J., \& Xu, S. (2020). Clinical features and outcomes of discharged coronavirus disease 2019 patients: A prospective cohort study. QJM, 113(9), 657-665.

Wu, Z., \& McGoogan, J. M. (2020). Characteristics of and Important Lessons from the Coronavirus Disease 2019 (COVID-19) Outbreak in China: Summary of a Report of 72314 Cases from the Chinese Center for Disease Control and Prevention. JAMA, 323(13), 1239-1242. 